\title{
WEIGHTED INTEGRAL INEQUALITY FOR THE SECOND DERIVATIVE OF 4-CONVEX FUNCTIONS
}

\author{
Josip PeČarić, Muhammad Shoaib SaleEm, \\ IRSHAAD AHMED AND NAVEED AHMED
}

\begin{abstract}
In this paper, we establish an energy estimate for the second derivative of 4 -convex functions. Such kinds of estimates for the first derivative of 2 -convex (convex) functions were obtained by Hussain, Pečarić and Shashivili [5].
\end{abstract}

Mathematics subject classification (2010): 46B70.

Keywords and phrases: 4-convex functions, mollification, energy estimate.

\section{REFERENCES}

[1] Z. Boros AND N. NAGY, Generalized Rolewicz theorem for convexity of higher order, Math. Inequal. Appl. 18, 4 (2015), 1275-1281.

[2] G. Cristescu, M. A. Noor AND M. U. Awan, Some inequalities for functions having an s-convex derivative of superior order, Math. Inequal. Appl. 19, 3 (2016), 893-907.

[3] S. S. Dragomir, Symmetrized convexity and Hermite-Hadamard type inequalities, J. Math. Inequal. 10, 4 (2016), 901-918.

[4] L. C. Evans, Partial Differential Equations, Graduate Studies in Mathematics 19, American Mathematical Society, Providence, RI, 1998.

[5] S. Hussain, J. PeČarić, And M. Shashiashvili, The weighted square integral inequalities for the first derivative of the function of a real variable, J. Inequal. Appl. 2008, Art. ID 343024, 14 pp.

[6] S. Hussain And M. Shashiashvili, Discrete time hedging of the American option, Mathematical Finance, 20 (2010), 647-670.

[7] A. R. KhAN, J. PeČARIĆ AND S. VARošAneC, Positivity of sums and integrals for convex functions of higher order of $n$ variables, Math. Inequal. Appl. 19, 1 (2016), 221-247.

[8] A. Olbryś, On some inequalities equivalent to the Wright-convexity, J. Math. Inequal. 9, 2 (2015), 449-461.

[9] J. PeČARIĆ AND K. SMOLJaK Steffensen type inequalities involving convex functions, Math. Inequal. Appl. 18, 1 (2015), 363-378.

[10] J. PeČARIĆ AND M. PraljaK, Hermite interpolation and inequalities involving weighted averages of $n$-convex functions, Math. Inequal. Appl. 19, 4 (2016), 1169-1180.

[11] J. PeČAriĆ, D. POKAZ AND M. PraljaK, Boas-type inequality for 3-convex functions at a point Math. Inequal. Appl. 19, 4 (2016), 1363-1374.

[12] T. RAJBA, On strong delta-convexity and Hermite-Hadamard type inequalities for delta-convex functions of higher order, Math. Inequal. Appl. 18, 1 (2015), 267-293.

[13] K. ShashiashVili AND M. ShashiashVili, Estimation of the derivative of the convex function by means of its uniform approximation, J. Inequal. Pure and Appl. Math., vol. 6, no. 4, article 113, pp. $1-10,2005$.

[14] J. E. PeČarić, F. Proschan and Y. L. Tong, Convex functions, Partial Orderings and Statistical Applications, Academic Press, New York, 1992.

[15] A. W. Roberts and D. E. Varberg, Convex Functions, Academic Press, New York, 1973. 